\title{
Non-Lead Protective Aprons for the Protection of Interventional Radiology Physicians from Radiation Exposure in Clinical Settings: An Initial Study
}

\author{
Mamoru Kato ${ }^{1,2}$, Koichi Chida ${ }^{1,3, *}$, Masato Munehisa ${ }^{2,4}$, Tadaya Sato ${ }^{2,5}$, Yohei Inaba ${ }^{1,3}$ (), \\ Masatoshi Suzuki ${ }^{1,3}{ }^{-1}$ and Masayuki Zuguchi ${ }^{1}$ \\ 1 Course of Radiological Technology, Health Sciences, Tohoku University Graduate School of Medicine, \\ 2-1 Seiryo, Aoba-ku, Sendai 980-8575, Japan; kato-amc@med.tohoku.ac.jp (M.K.); \\ inaba@med.tohoku.ac.jp (Y.I.); msuzuki@irides.tohoku.ac.jp (M.S.); qqrm6wq9k@arrow.ocn.ne.jp (M.Z.) \\ 2 Akita Cerebrospinal and Cardiovascular Center (Akita Medical Center), 6-10 Senshu-Kubota Machi, \\ Akita 010-0874, Japan; masatom1025@gmail.com (M.M.); tsatotan@gmail.com (T.S.) \\ 3 Department of Radiation Disaster Medicine, International Research Institute of Disaster Science, \\ Tohoku University, 468-1 Aramaki Aza-Aoba, Aoba-ku, Sendai 980-0845, Japan \\ 4 Department of Cardiovascular Medicine, Senseki Hospital, 53-7 Akai, Aza Dai, \\ Higashi Matsushima 981-0501, Japan \\ 5 Department of Cardiovascular Medicine, Saka General Hospital, 16-5 Nishiki-machi, \\ Shiogama 985-8506, Japan \\ * Correspondence: chida@med.tohoku.ac.jp; Tel.: +81-22-717-7943
}

\section{check for} updates

Citation: Kato, M.; Chida, K.; Munehisa, M.; Sato, T.; Inaba, Y.; Suzuki, M.; Zuguchi, M. Non-Lead Protective Aprons for the Protection of Interventional Radiology Physicians from Radiation Exposure in Clinical Settings: An Initial Study. Diagnostics 2021, 11, 1613. https://doi.org/10.3390/ diagnostics11091613

Academic Editor: Felix G. Meinel

Received: 31 July 2021

Accepted: 30 August 2021

Published: 3 September 2021

Publisher's Note: MDPI stays neutral with regard to jurisdictional claims in published maps and institutional affiliations.

Copyright: (c) 2021 by the authors. Licensee MDPI, Basel, Switzerland. This article is an open access article distributed under the terms and conditions of the Creative Commons Attribution (CC BY) license (https:// creativecommons.org/licenses/by/ $4.0 /)$.

\begin{abstract}
Radiation protection/evaluation during interventional radiology (IVR) poses a very important problem. Although IVR physicians should wear protective aprons, the IVR physician may not tolerate wearing one for long procedures because protective aprons are generally heavy. In fact, orthopedic problems are increasingly reported in IVR physicians due to the strain of wearing heavy protective aprons during IVR. In recent years, non-Pb protective aprons (lighter weight, composite materials) have been developed. Although non- $\mathrm{Pb}$ protective aprons are more expensive than $\mathrm{Pb}$ protective aprons, the former aprons weigh less. However, whether the protective performance of non- $\mathrm{Pb}$ aprons is sufficient in the IVR clinical setting is unclear. This study compared the ability of non- $\mathrm{Pb}$ and $\mathrm{Pb}$ protective aprons $(0.25$ - and $0.35-\mathrm{mm} \mathrm{Pb}$-equivalents) to protect physicians from scatter radiation in a clinical setting (IVR, cardiac catheterizations, including percutaneous coronary intervention) using an electric personal dosimeter (EPD). For radiation measurements, physicians wore EPDs: One inside a personal protective apron at the chest, and one outside a personal protective apron at the chest. Physician comfort levels in each apron during procedures were also evaluated. As a result, performance (both the shielding effect (98.5\%) and comfort (good)) of the non- $\mathrm{Pb}$ $0.35-\mathrm{mm}$-Pb-equivalent protective apron was good in the clinical setting. The radiation-shielding effects of the non- $\mathrm{Pb} 0.35-\mathrm{mm}$ and $\mathrm{Pb} 0.35-\mathrm{mm}-\mathrm{Pb}$-equivalent protective aprons were very similar. Therefore, non- $\mathrm{Pb} 0.35-\mathrm{mm} \mathrm{Pb}$-equivalent protective aprons may be more suitable for providing radiation protection for IVR physicians because the shielding effect and comfort are both good in the clinical IVR setting. As non- $\mathrm{Pb}$ protective aprons are nontoxic and weigh less than $\mathrm{Pb}$ protective aprons, non- $\mathrm{Pb}$ protective aprons will be the preferred type for radiation protection of IVR staff, especially physicians.
\end{abstract}

Keywords: radiation protection; fluoroscopy; interventional radiology (IVR); fluoroscopically guided interventional procedures; percutaneous coronary intervention (PCI); protective apron; radiation safety; radiation dose; X-ray examination; disaster medicine

\section{Introduction}

The occupational exposure and patient radiation dose are important issues [1-5]. Especially, interventional radiology (IVR) procedures deliver high radiation doses to both 
the physician and patient [6-14]. Furthermore, IVR physicians are at high risk of radiationinduced injury [15-20]. Thus, radiation evaluation/protection is very important to the IVR physician [21-25].

Although physicians should wear protective aprons, the IVR physician may not tolerate wearing one for long procedures because protective aprons are generally heavy. In fact, orthopedic problems are increasingly reported in IVR physicians due to the strain of wearing heavy aprons during IVR [26-28].

Recently, non-lead $(\mathrm{Pb})$ protective aprons (lighter weight, composite materials) have been developed $[29,30]$. Although non- $\mathrm{Pb}$ protective aprons are more expensive than $\mathrm{Pb}$ protective aprons, the former protective aprons weigh less. Furthermore, non- $\mathrm{Pb}$ protective aprons are environmentally friendly. $\mathrm{Pb}$ toxicity is obviously not in play. Thus, non- $\mathrm{Pb}$ protective aprons are optimal. However, whether the protective performance of non- $\mathrm{Pb}$ aprons is sufficient in the IVR clinical setting is unclear. Furthermore, the optimal $\mathrm{Pb}$ equivalent of protective aprons, 0.25 - and $0.35-\mathrm{mm} \mathrm{Pb}$-equivalents, is unclear in the IVR clinical setting.

This study compared the ability of non- $\mathrm{Pb}$ and $\mathrm{Pb}$ protective aprons $(0.25-$ and $0.35-\mathrm{mm} \mathrm{Pb}$-equivalents) to protect physicians from scatter radiation in a clinical setting (cardiac catheterizations, including percutaneous coronary intervention, $\mathrm{PCI}$ ) using an electric personal dosimeter (EPD). Physician comfort levels in each apron during procedures were also evaluated.

The purpose of this initial study was to demonstrate the effectiveness of non-lead protective aprons for the protection of IVR physicians from radiation exposure in clinical settings.

\section{Materials and Methods}

\subsection{Protective Apron and Radiation Measurement}

In this study, physicians wore one of four types of protective apron at random: $0.25-\mathrm{mm} \mathrm{Pb}$ (QA 0.25, Kasei-optonics, Odawara, Japan), 0.35-mm Pb (QA 0.35, Kasei-optonics, Odawara, Japan), non-Pb, 0.25-mm Pb-equivalent (HGA 0.25, Kasei-optonics, Odawara, Japan), or non-Pb, 0.35-mm Pb-equivalent (HGA 0.35, Kasei-optonics, Odawara, Japan). Pb protective aprons consist of lead. Non-lead protective aprons consist of composite materials, mainly tungsten (W) and tin (Sn).

For radiation measurements, physicians wore two EPDs (PDM-117, Hitachi-Aloka, Taito$\mathrm{ku}$, Japan): One inside a personal protective apron at the chest, and one outside a personal protective apron at the chest. Figure 1 indicates the position of each EPD in the clinical setting (cardiac catheterizations, including PCI). We evaluated external (average dose of exterior EPDs at the chest) and internal doses (average dose of interior EPDs at the chest).

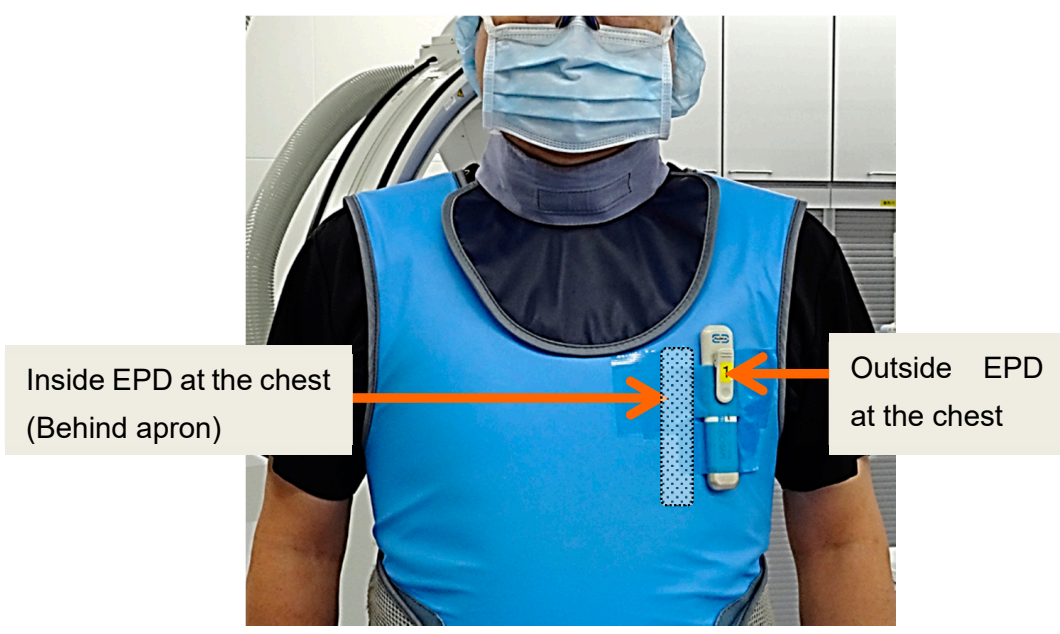

Figure 1. The position of the two electric personal dosimeters (EPDs) worn on the physician's protective apron in a clinical setting. 
The radiation shielding effects (\%) of the protective aprons were also determined as follows:

Radiation shielding effects $(\%)=(1-$ inside dose $/$ outside dose $) \times 100$.

\subsection{Cardiac Catheterization}

Radiation exposure (external and internal radiation dose) for the two physicians during more than 50 cardiac catheterizations (including PCI) with the four types of protective apron were measured randomly at Akita Medical Center (Akita, Akita, Japan) (Table 1). We did not establish inclusion or exclusion criteria for this initial study. During each procedure, physicians were at liberty to choose any of the four types of protective apron.

Table 1. A summary of our study.

\begin{tabular}{cccccc}
\hline $\begin{array}{c}\text { Protective Apron } \\
\text { Pb-Equivalent [mm] }\end{array}$ & Total & $\begin{array}{c}\text { Number of Procedures } \\
\text { CAG }\end{array}$ & PCI & $\begin{array}{c}\text { Cumulative AK } \\
\text { [Mean } \pm \text { SD, mGy] }\end{array}$ & $\begin{array}{c}\text { Fluoroscopy Time } \\
{[\text { Mean } \pm \text { SD, min] }}\end{array}$ \\
\hline $\begin{array}{c}\text { Non-lead } \\
0.25\end{array}$ & 78 & 32 & 46 & $1345.7 \pm 1378.9$ & $34.5 \pm 27.7$ \\
\hline $\begin{array}{c}\text { Non-lead } \\
0.35\end{array}$ & 51 & 19 & 27 & $1345.3 \pm 1637.3$ & $31.7 \pm 27.1$ \\
\hline $\begin{array}{c}\text { Lead } \\
0.25\end{array}$ & 50 & 23 & 27 & $1037.2 \pm 824.7$ & $30.4 \pm 21.7$ \\
\hline $\begin{array}{c}\text { Lead } \\
0.35\end{array}$ & 50 & 26 & 24 & $812.3 \pm 704.9$ & $21.2 \pm 15.5$ \\
\hline
\end{tabular}

AK: Air karma, CAG: Coronary angiography, PCI: Percutaneous coronary intervention.

In this study, an additional lead acrylic protection device was also used, if possible, during procedures (Figure 2).

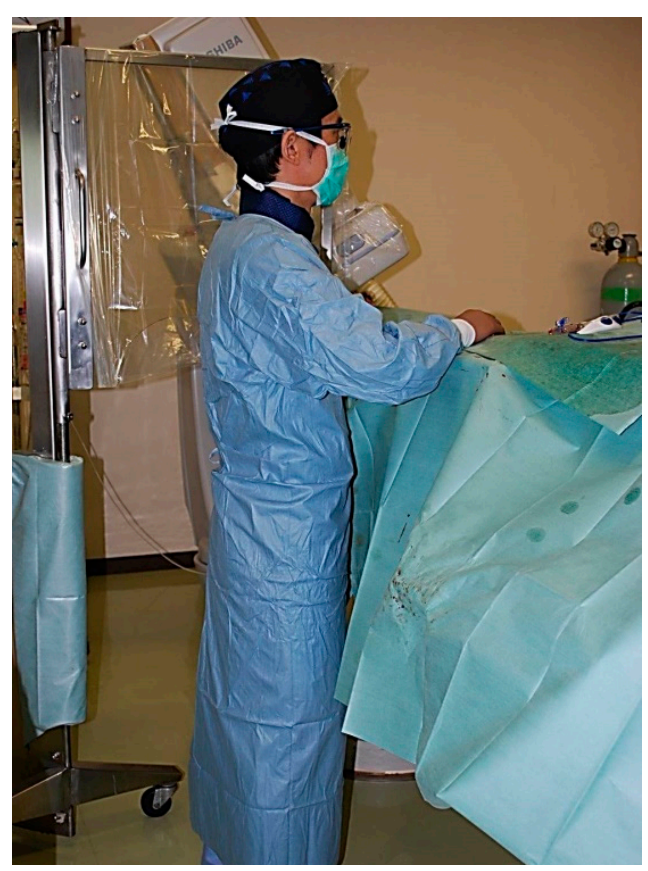

Figure 2. Photograph during the cardiac catheterization procedure.

Physician comfort levels in each protective apron during cardiac catheterizations procedures (including PCI) were also determined through interviews.

The procedures (cardiac catheterizations, including PCI) were performed using a digital cine X-ray single-plane system (Infinix Celeve-i, Toshiba, Ohtawara, Japan) with a 7-inch mode flat-panel detector, an acquisition (cine) rate of 15 frames/s, and pulsed fluoroscopy (15 pulses/s). 
This study was approved by the Ethics Committee of Akita Cerebrospinal and Cardiovascular Center (Akita Medical Center). We also evaluated the radiation dose indicator (cumulative air karma $[\mathrm{AK}]$ ) and fluoroscopy time undergoing cardiac catheterizations, including PCI.

\section{Results}

The X-ray procedure details used in cardiac catheterizations (including PCI) are shown in Table 1. Table 2 summarizes the findings of this clinical study. Although the radiationshielding effect of the $0.35-\mathrm{mm} \mathrm{Pb}$ protective apron was the best $(98.9 \%)$ among the four types, physician comfort was the worst (very poor) because this protective apron was the heaviest. Conversely, although physician comfort in the non- $\mathrm{Pb} 0.25-\mathrm{mm} \mathrm{Pb}$-equivalent protective apron was highest (excellent) among the types because the protective apron was the lightest, the radiation shielding effect was the worst (96.1\%).

Table 2. Summary of our study on the performance of protective aprons in the clinical setting. Each was used for more than 50 catheterizations, including PCI.

\begin{tabular}{|c|c|c|c|c|c|}
\hline Protective Apron & Apron Weight & Outside (External) Dose & Inside (Internal) Dose & Shielding Effects & Comfortably \\
\hline Pb-Equivalent [mm] & [kg] & {$[\mathrm{Mean} \pm \mathrm{SD}, \mu \mathrm{Sv}]$} & {$[$ Mean \pm SD, $\mu$ Sv] } & {$[\%]$} & Comfortabiy \\
\hline $\begin{array}{c}\text { Non-lead } \\
0.25\end{array}$ & 1.8 & $142.6 \pm 199.3$ & $5.5 \pm 7.1$ & 96.1 & Excellent \\
\hline $\begin{array}{c}\text { Non-lead } \\
0.35\end{array}$ & 2.9 & $123.9 \pm 99.3$ & $1.8 \pm 1.5$ & 98.5 & Good \\
\hline $\begin{array}{l}\text { Lead } \\
0.25\end{array}$ & 3.0 & $166.4 \pm 153.6$ & $4.6 \pm 4.7$ & 97.3 & Somewhat poor \\
\hline $\begin{array}{c}\text { Lead } \\
0.35\end{array}$ & 3.8 & $209.2 \pm 163.1$ & $2.2 \pm 1.9$ & 98.9 & Very poor \\
\hline
\end{tabular}

The performance (both the shielding effect (98.5\%) and comfort (good)) of the non- $\mathrm{Pb}$ $0.35-\mathrm{mm}-\mathrm{Pb}$-equivalent protective apron was good in the clinical setting. The radiationshielding effects of the $0.35-\mathrm{mm} \mathrm{Pb}$ and non- $\mathrm{Pb} 0.35-\mathrm{mm}$ - $\mathrm{Pb}$-equivalent protective aprons were very similar. The extent of physician comfort when wearing the non- $\mathrm{Pb} 0.35-\mathrm{mm}-$ $\mathrm{Pb}$-equivalent protective apron was similar to that when wearing the non- $\mathrm{Pb} 0.25-\mathrm{mm}-\mathrm{Pb}$ equivalent protective apron. Thus, non- $\mathrm{Pb} 0.35-\mathrm{mm} \mathrm{Pb}$-equivalent protective aprons may be more suitable in providing radiation protection for IVR physicians. Thus, we recommend that IVR physicians should wear the non- $\mathrm{Pb} 0.35-\mathrm{mm}$ - $\mathrm{Pb}$-equivalent protective apron.

\section{Discussion}

In X-ray examination, radiation protection/evaluation of physicians and patients is significant. Although the wide acceptance of IVR procedures, such as PCI, has led to increasing numbers of interventions being performed, radiation exposures from IVR are conclusively higher, exposing both the IVR staff and the patient to high radiation doses. [31-39].

Many radiation-related injuries caused by excessive radiation exposure during cardiac intervention IVR procedures have been reported [40-43]. Therefore, radiation monitoring for physicians is essential in reducing the radiation injury risk during IVR. Furthermore, most IVR physicians stand close to the patient where the scattered radiation and consequently the physicians' exposure is higher. Therefore, radiation protection/measurement for the physician during IVR poses a very important problem [44-54].

A protective apron is inevitably heavy but should be worn by all staff working in catheterization suites. The protective aprons increase the risk of musculoskeletal disorders. Careful selection of a personal protective apron is thus important $[55,56]$.

As non-lead aprons consist of composite materials, mainly W and Sn, they are approximately $20 \%$ lighter than lead aprons $[29,30]$. In the phantom study, the performance of these non- $\mathrm{Pb}$ and $\mathrm{Pb}$ protective aprons was similar for scattered $\mathrm{X}$-rays [30]. However, whether the performance (both shielding effect and comfort) of non-Pb aprons is sufficient 
in the clinical setting (cardiac catheterizations including PCI) is unclear. In this study, the radiation protection provided by non- $\mathrm{Pb}$ and $\mathrm{Pb}$ protective aprons in clinical IVR settings are compared. As a result, we demonstrated the effectiveness of non-Pb protective aprons for the protection of IVR physicians from radiation exposure in clinical IVR settings.

Namely, our results showed that the performance (both shielding effect and comfort) of the non- $\mathrm{Pb} 0.35-\mathrm{mm} \mathrm{Pb}$-equivalent protective apron was good in the clinical setting (cardiac catheterizations including $\mathrm{PCI}$ ). Thus, non- $\mathrm{Pb} 0.35-\mathrm{mm} \mathrm{Pb}$-equivalent protective aprons may be more suitable in providing radiation protection for IVR physicians.

For procedures during which non-lead protective aprons were worn, the mean external dose tended to be lower than that when lead protective aprons were worn (non-lead protective aprons 142.6 or $123.9 \mu \mathrm{Sv}$; lead protective aprons 166.4 or $209.2 \mu \mathrm{Sv}$, Table 2). Moreover, the cumulative AK was higher (non-lead protective aprons 1345.7 or $1345.3 \mathrm{mGy}$, lead protective aprons 1037.2 or $812.3 \mathrm{mGy}$, Table 1) and the fluoroscopy time longer (nonlead protective aprons 34.5 or $31.7 \mathrm{~min}$, lead aprons 30.4 or $21.2 \mathrm{~min}$, Table 1). The probable explanation is that an additional, lead-containing, acrylic protection device was employed during many procedures featuring non-lead protective aprons. Thus, if the cumulative AK was higher, the external dose was lower because the non-apron device shielded staff from scattered radiation. We did not evaluate the effect of the non-apron device because the shielding effect $(\%)$ is relative.

Possible ergonomic improvements include the use of a two-part protective apron (that separately protects the chest and waist). This would distribute the protective apron weight more equally across the shoulders and waist, possibly reducing the risk of musculoskeletal pain [56].

\section{Limitation}

This was an initial study of non- $\mathrm{Pb}$ protective apron use in clinical settings. A controlled comparison of four groups (wearing non- $\mathrm{Pb}$ and $\mathrm{Pb}$ protective aprons; 0.25 - and 0.35 -mm-Pb-equivalents), with statistical evaluation, is necessary.

\section{Conclusions}

This study compared the protective performance of $\mathrm{Pb}$ and non- $\mathrm{Pb}$ aprons of $0.25-\mathrm{mm}$ and $0.35-\mathrm{mm} \mathrm{Pb}$-equivalents in the clinical setting (cardiac catheterizations including PCI). $\mathrm{Non}-\mathrm{Pb}$ 0.35-mm $\mathrm{Pb}$-equivalent protective aprons may be more suitable for providing radiation protection for IVR physicians because the shielding effect and comfort are both good in the clinical setting.

As non- $\mathrm{Pb}$ protective aprons are nontoxic and weigh less than $\mathrm{Pb}$ protective aprons, and IVR staff mainly receive doses from scattered X-rays, non- $\mathrm{Pb}$ protective aprons will be the preferred type for radiation protection of IVR staff, especially physicians.

Author Contributions: Conceptualization, M.K. and K.C.; methodology, M.K. and K.C.; software, M.K. and Y.I.; validation, K.C., M.S., and M.Z.; formal analysis, M.K., M.M., and T.S.; investigation, M.K., M.M., and T.S.; resources, K.C.; data curation, M.K., Y.I., and M.S.; writing-original draft preparation, M.K.; writing - review and editing, M.K. and K.C.; visualization, M.K. and Y.I.; supervision, K.C. and M.Z.; project administration, K.C. All authors have read and agreed to the published version of the manuscript.

Funding: This study was supported in part by the Industrial Disease Clinical Research Grants (200701-1), Japan.

Institutional Review Board Statement: The study was conducted according to the guidelines of the Declaration of Helsinki, and approved by the Institutional Review Board of Akita Cerebrospinal and Cardiovascular Center (Akita Medical Center), (IRB approval number: 21-11).

Informed Consent Statement: Informed consent was obtained from all subjects involved in the study.

Acknowledgments: We thank Hiroki Ishii, Tohoku university hospital, Japan, and Yoshihiro Haga of the Sendai Kousei Hospital, Japan for their invaluable assistance. 
Conflicts of Interest: The authors declare no conflict of interest. The funders had no role in the design of the study; in the collection, analyses, or interpretation of data; in the writing of the manuscript, or in the decision to publish the results.

\section{References}

1. Nemoto, M.; Chida, K. Reducing the breast cancer risk and radiation dose of radiography for scoliosis in children: A phantom study. Diagnostics 2020, 10, 753. [CrossRef] [PubMed]

2. International Commission on Radiological Protection (ICRP). Radiological Protection and Safety in Medicine; ICRP Publication 73; Pergamon: Oxford, UK, 1996; Volume 26, Available online: https://journals.sagepub.com/doi/pdf/10.1177/ANIB_26_2 (accessed on 28 August 2021).

3. Vano, E. Challenges for managing the cumulative effective dose for patients. Br. J. Radiol. 2020, 93, 20200814. [CrossRef]

4. International Commission on Radiological Protection (ICRP). Diagnostic Reference Levels in Medical Imaging; ICRP Publication 135; Sage: Thousand Oaks, CA, USA, 2017; Volume 46, Available online: https://journals.sagepub.com/doi/pdf/10.1177/ANIB_46_1 (accessed on 28 August 2021).

5. Morishima, Y.; Chida, K.; Watanabe, H. Estimation of the dose of radiation received by patient and physician during a videofluoroscopic swallowing study. Dysphagia 2016, 31, 574-578. [CrossRef] [PubMed]

6. Haga, Y.; Chida, K.; Sota, M.; Kaga, Y.; Abe, M.; Inaba, Y.; Suzuki, M.; Meguro, T.; Zuguchi, M. Hybrid operating room system for the treatment of thoracic and abdominal aortic aneurysms: Evaluation of the radiation dose received by patients. Diagnostics 2020, 10, 846. [CrossRef] [PubMed]

7. Chida, K.; Kato, M.; Kagaya, Y.; Zuguchi, M.; Saito, H.; Ishibashi, T.; Takahashi, S.; Yamada, S.; Takai, Y. Radiation dose and radiation protection for patients and physicians during interventional procedure. J. Radiat. Res. 2010, 51, 97-105. [CrossRef] [PubMed]

8. Chida, K.; Inaba, Y.; Masuyama, H.; Yanagawa, I.; Mori, I.; Saito, H.; Maruoka, S.; Zuguchi, M. Evaluating the performance of a MOSFET dosimeter at diagnostic X-ray energies for interventional radiology. Radiol. Phys. Technol. 2009, 2, 58-61. [CrossRef]

9. Inaba, Y.; Chida, K.; Murabayashi, Y.; Endo, M.; Otomo, K.; Zuguchi, M. An initial investigation of a wireless patient radiation dosimeter for use in interventional radiology. Radiol. Phys. Technol. 2020, 13, 1-6. [CrossRef] [PubMed]

10. Chida, K.; Kato, M.; Inaba, Y.; Kobayashi, R.; Nakamura, M.; Abe, Y.; Zuguchi, M. Real-time patient radiation dosimeter for use in interventional radiology. Phys. Medica 2016, 32, 1475-1478. [CrossRef]

11. Chida, K.; Saito, H.; Zuguchi, M.; Shirotori, K.; Kumagai, S.; Nakayama, H.; Matsubara, K.; Kohzuki, M. Does digital acquisition reduce patients' skin dose in cardiac interventional procedures? An experimental study. Am. J. Roentgenol. 2004, 183, 1111-1114. [CrossRef]

12. International Commission on Radiological Protection (ICRP). Radiological Protection in Medicine; ICRP Publication 105; Elsevier: Amsterdam, The Netherlands, 2007; Volume 37, Available online: https://journals.sagepub.com/doi/pdf/10.1177/ANIB_37_6 (accessed on 28 August 2021).

13. Chida, K.; Saito, H.; Otani, H.; Kohzuki, M.; Takahashi, S.; Yamada, S.; Shirato, K.; Zuguchi, M. Relationship between fluoroscopic time, dose-Area product, body weight, and maximum radiation skin dose in cardiac interventional procedures. Am. J. Roentgenol. 2006, 186, 774-778. [CrossRef]

14. Chida, K.; Kagaya, Y.; Saito, H.; Takai, Y.; Takahashi, S.; Yamada, S.; Kohzuki, M.; Zuguchi, M. Total entrance skin dose: An effective indicator of maximum radiation dose to the skin during percutaneous coronary intervention. Am. J. Roentgenol. 2007, 189, W224-W227. [CrossRef]

15. International Commission on Radiological Protection (ICRP). ICRP Statement on Tissue Reactions / Early and Late Effects of Radiation in Normal Tissues and Organs_Threshold Doses for Tissue Reactions in a Radiation Protection Context; ICRP Publication 118; Elsevier: Amsterdam, The Netherlands, 2012; Volume 41, Available online: https://journals.sagepub.com/doi/pdf/10.1177/ANIB_41_1-2 (accessed on 28 August 2021).

16. Chida, K.; Kaga, Y.; Haga, Y.; Kataoka, N.; Kumasaka, E.; Meguro, T.; Zuguchi, M. Occupational dose in interventional radiology procedures. Am. J. Roentgenol. 2013, 200, 138-141. [CrossRef]

17. Attigah, N.; Oikonomou, K.; Hinz, U.; Knoch, T.; Demirel, S.; Verhoeven, E.; Böckler, D. Radiation exposure to eye lens and operator hands during endovascular procedures in hybrid operating rooms. J. Vasc. Surg. 2016, 63, 198-203. [CrossRef] [PubMed]

18. Haga, Y.; Chida, K.; Kaga, Y.; Sota, M.; Meguro, T.; Zuguchi, M. Occupational eye dose in interventional cardiology procedures. Sci. Rep. 2017, 7, 1-7. [CrossRef] [PubMed]

19. Presidência da República. Casa Civil. Subchefia para Assuntos Jurídicos. Decreto—Lei no 227, De 28 de Fevereiro de 1967. Dá Nova Redação ao Decreto-lei no 1.985, de 29 de Janeiro de 1940 (Código de Minas). 1967. Available online: http:/ / www.planalto. gov.br/ccivil_03/Decreto-Lei/Del0227.htm (accessed on 19 October 2020).

20. Ishii, H.; Chida, K.; Satsurai, K.; Haga, Y.; Kaga, Y.; Abe, M.; Inaba, Y.; Zuguchi, M. A phantom study to determine the optimal placement of eye dosemeters on interventional cardiology staff. Radiat. Prot. Dosim. 2019, 185, 409-413. [CrossRef] [PubMed]

21. Martin, C.J.; Magee, J.S. Assessment of eye and body dose for interventional radiologists, cardiologists, and other interventional staff. J. Radiol. Prot. 2013, 33, 445-460. [CrossRef] 
22. Chida, K.; Morishima, Y.; Masuyama, H.; Chiba, H.; Katahira, Y.; Inaba, Y.; Mori, I.; Maruoka, S.; Takahashi, S.; Kohzuki, M.; et al. Effect of radiation monitoring method and formula differences on estimated physician dose during percutaneous coronary intervention. Acta Radiol. 2009, 50, 170-173. [CrossRef]

23. Vano, E.; Sanchez, R.M.; Fernández, J.M. Strategies to optimise occupational radiation protection in interventional cardiology using simultaneous registration of patient and staff doses. J. Radiol. Prot. 2018, 38, 1077-1088. [CrossRef] [PubMed]

24. Kato, M.; Chida, K.; Ishida, T.; Toyoshima, H.; Yoshida, Y.; Yoshioka, S.; Moroi, J.; Kinoshita, T. Occupational radiation ex-posure of the eye in neurovascular interventional physician. Radiat. Prot. Dosim. 2019, 185, 151-156. [CrossRef]

25. Kato, M.; Chida, K.; Ishida, T.; Sasaki, F.; Toyoshima, H.; Oosaka, H.; Terata, K.; Abe, Y.; Kinoshita, T. Occupational radiation exposure dose of the eye in department of cardiac arrhythmia physician. Radiat. Prot. Dosim. 2019, 187, 361-368. [CrossRef]

26. Ross, A.M.; Segal, J.; Borenstein, D.; Jenkins, E.; Cho, S. Prevalence of spinal disc disease among interventional cardiologists. Am. J. Cardiol. 1997, 79, 68-70. [CrossRef]

27. Goldstein, J.A.; Balter, S.; Cowley, M.; Hodgson, J.; Klein, L.W. Interventional committee of the society of cardiovascular interventions occupational hazards of interventional cardiologists: Prevalence of orthopedic health problems in contemporary practice. Catheter. Cardiovasc. Interv. 2004, 63, 407-411. [CrossRef]

28. Pleis, J.R.; Ward, B.W.; Lucas, J.W. Summary health statistics for US adults: National Health Interview Survey, 2009. Vital Health Stat. 2010, 249, 1-207.

29. Yaffe, M.J.; Mawdsley, G.E.; Lilley, M.; Servant, R.; Reh, G. Composite materials for X-ray protection. Health Phys. 1991, 60, 661-664. [CrossRef]

30. Zuguchi, M.; Chida, K.; Taura, M.; Inaba, Y.; Ebata, A.; Yamada, S. Usefulness of non-lead aprons in radiation protection for physicians performing interventional procedures. Radiat. Prot. Dosim. 2008, 131, 531-534. [CrossRef]

31. Chida, K.; Inaba, Y.; Saito, H.; Ishibashi, T.; Takahashi, S.; Kohzuki, M.; Zuguchi, M. Radiation dose of interventional radiology system using a flat-panel detector. Am. J. Roentgenol. 2009, 193, 1680-1685. [CrossRef]

32. Chida, K.; Ohno, T.; Kakizaki, S.; Takegawa, M.; Yuuki, H.; Nakada, M.; Takahashi, S.; Zuguchi, M. Radiation dose to the pediatric cardiac catheterization and intervention patient. Am. J. Roentgenol. 2010, 195, 1175-1179. [CrossRef]

33. Chida, K.; Inaba, Y.; Morishima, Y.; Taura, M.; Ebata, A.; Yanagawa, I.; Takeda, K.; Zuguchi, M. Comparison of dose at an interventional reference point between the displayed estimated value and measured value. Radiol. Phys. Technol. 2011, 4, 189-193. [CrossRef] [PubMed]

34. Inaba, Y.; Nakamura, M.; Chida, K.; Zuguchi, M. Effectiveness of a novel real-time dosimeter in interventional radiology: A comparison of new and old radiation sensors. Radiol. Phys. Technol. 2018, 11, 445-450. [CrossRef] [PubMed]

35. International Commission on Radiological Protection (ICRP). Radiological Protection in Cardiology; ICRP Publication 120; Elsevier: Amsterdam, The Netherlands, 2013; Volume 42, Available online: https://journals.sagepub.com/doi/pdf/10.1177/ANIB_42_1 (accessed on 28 August 2021).

36. Inaba, Y.; Nakamura, M.; Zuguchi, M.; Chida, K. Development of novel real-time radiation systems using 4-channel sensors. Sensors 2020, 20, 2741. [CrossRef] [PubMed]

37. Kato, M.; Chida, K.; Nakamura, M.; Toyoshima, H.; Terata, K.; Abe, Y. New real-time patient radiation dosimeter for use in radiofrequency catheter ablation. J. Radiat. Res. 2019, 60, 215-220. [CrossRef]

38. Inaba, Y.; Chida, K.; Kobayashi, R.; Zuguchi, M. A cross-sectional study of the radiation dose and image quality of X-ray equipment used in IVR. J. Appl. Clin. Med. Phys. 2016, 17, 391-401. [CrossRef] [PubMed]

39. Chida, K.; Kato, M.; Saito, H.; Ishibashi, T.; Takahashi, S.; Kohzuki, M.; Zuguchi, M. Optimizing patient radiation dose in intervention procedures. Acta Radiol. 2010, 51, 33-39. [CrossRef]

40. International Commission on Radiological Protection (ICRP). Avoidance of Radiation Injuries from Medical Interventional Procedures; ICRP Publication 85; Pergamon: Oxford, UK, 2000; Volume 30, Available online: https://journals.sagepub.com/doi/pdf/10.117 7/ANIB_30_2 (accessed on 28 August 2021).

41. Vañó, E.; González, L.; Beneytez, F.; Moreno, F. Lens injuries induced by occupational exposure in non-optimized interventional radiology laboratories. Br. J. Radiol. 1998, 71, 728-733. [CrossRef]

42. Kato, M.; Chida, K.; Sato, T.; Oosaka, H.; Tosa, T.; Munehisa, M.; Kadowaki, K. The necessity of follow-up for radiation skin injuries in patients after percutaneous coronary interventions: Radiation skin injuries will often be overlooked clinically. Acta Radiol. 2012, 53, 1040-1044. [CrossRef] [PubMed]

43. Koenig, A.; Maas, J.; Viniol, S.; Etzel, R.; Fiebich, M.; Thomas, R.; Mahnken, A. Scatter radiation reduction with a radiationabsorbing pad in interventional radiology examinations. Eur. J. Radiol. 2020, 132, 109245. [CrossRef]

44. Chida, K.; Takahashi, T.; Ito, D.; Shimura, H.; Takeda, K.; Zuguchi, M. Clarifying and visualizing sources of staff-received scattered radiation in interventional procedures. Am. J. Roentgenol. 2011, 197, W900-W903. [CrossRef]

45. Chida, K.; Morishima, Y.; Inaba, Y.; Taura, M.; Ebata, A.; Takeda, K.; Shimura, H.; Zuguchi, M. Physician-received scatter radiation with angiography systems used for interventional radiology: Comparison among many X-ray systems. Radiat. Prot. Dosim. 2011, 149, 410-416. [CrossRef] [PubMed]

46. Inaba, Y.; Chida, K.; Kobayashi, R.; Kaga, Y.; Zuguchi, M. Fundamental study of a real-time occupational dosimetry system for interventional radiology staff. J. Radiol. Prot. 2014, 34, N65-N71. [CrossRef]

47. Kuon, E.; Schmitt, M.; Dahm, J.B. Significant reduction of radiation exposure to operator and staff during cardiac interventions by analysis of radiation leakage and improved lead shielding. Am. J. Cardiol. 2002, 89, 44-49. [CrossRef] 
48. Haga, Y.; Chida, K.; Kimura, Y.; Yamanda, S.; Sota, M.; Abe, M.; Kaga, Y.; Meguro, T.; Zuguchi, M. Radiation eye dose to medical staff during respiratory endoscopy under X-ray fluoroscopy. J. Radiat. Res. 2020, 61, 691-696. [CrossRef]

49. Endo, M.; Haga, Y.; Sota, M.; Tanaka, A.; Otomo, K.; Murabayashi, Y.; Abe, M.; Kaga, Y.; Inaba, Y.; Suzuki, M.; et al. Evaluation of novel X-ray protective eyewear in reducing the eye dose to interventional radiology physicians. J. Radiat. Res. 2021, 62, 414-419. [CrossRef]

50. Inaba, Y.; Hitachi, S.; Watanuki, M.; Chida, K. Occupational radiation dose to eye lenses in CT-guided interventions using MDCT-fluoroscopy. Diagnostics 2021, 11, 646. [CrossRef] [PubMed]

51. Morishima, Y.; Chida, K.; Muroya, Y.; Utsumi, Y. Effectiveness of a New lead-shielding device and additional filter for reducing staff and patient radiation exposure during videofluoroscopic swallowing study using a human phantom. Dysphagia 2018, 33, 109-114. [CrossRef] [PubMed]

52. Morishima, Y.; Chida, K.; Meguro, T. Effectiveness of additional lead shielding to protect staff from scattering radiation during endoscopic retrograde cholangiopancreatography procedures. J. Radiat. Res. 2018, 59, 225-232. [CrossRef] [PubMed]

53. Ishii, H.; Haga, Y.; Sota, M.; Inaba, Y.; Chida, K. Performance of the DOSIRIS ${ }^{\mathrm{TM}}$ eye lens dosimeter. J. Radiol. Prot. 2019, 39, N19-N26. [CrossRef]

54. Morishima, Y.; Chida, K.; Katahira, Y. The effectiveness of additional lead-shielding drape and low pulse rate fluoroscopy in protecting staff from scatter radiation during cardiac resynchronization therapy (CRT). Jpn. J. Radiol. 2019, 37, 95-101. [CrossRef]

55. Dixon, R.G.; Khiatani, V.; Statler, J.D.; Walser, E.M.; Midia, M.; Miller, D.L.; Bartal, G.; Collins, J.D.; Gross, K.A.; Stecker, M.S.; et al. Society of interventional radiology: Occupational back and neck pain and the interventional radiologist. J. Vasc. Interv. Radiol. 2017, 28, 195-199. [CrossRef] [PubMed]

56. Cornelis, F.H.; Razakamanantsoa, L.; Ammar, M.B.; Lehrer, R.; Haffaf, I.; El-Mouhadi, S.; Gardavaud, F.; Najdawi, M.; Barral, M. Ergonomics in interventional radiology: Awareness is mandatory. Medicina 2021, 57, 500. [CrossRef] 